MEDIATED MEMORIES IN THE DIGITAL AGE 

Cultural Memory

in

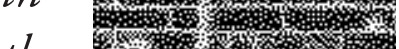

the 10 /

Present

Mieke Bal and Hent de Vries, Editors 



\section{MEDIATED MEMORIES IN THE DIGITAL AGE}

José van Dijck

STANFORD UNIVERSITY PRESS

STANFORD, CALIFORNIA

2007 
Stanford University Press

Stanford, California

(C) 2007 by the Board of Trustees of the Leland Stanford Junior University. All rights reserved.

No part of this book may be reproduced or transmitted in any form or by any means, electronic or mechanical, including photocopying and recording, or in any information storage or retrieval system without the prior written permission of Stanford University Press.

Printed in the United States of America on acid-free, archival-quality paper

Library of Congress Cataloging-in-Publication Data

Dijck, José van.

Mediated memories in the digital age / José van Dijck.

p. cm. - (Cultural memory in the present)

Includes bibliographical references and index.

ISBN 978-0-8047-5623-5 (cloth) — ISBN 978-0-8047-5624-2 (paper)

I. Image processing-Digital techniques 2. Multimedia systems.

3. Memory. I. Title.

TAi637.D57 2007

I53.I' $3-\mathrm{dc2} 2$

$200700864 \mathrm{I}$

Typeset by Westchester Book Group in II/13.5 Garamond 
They came to know the incorrigible sorrow of all prisoners and exiles, which is to live in company with a memory that serves no purpose. Even the past, of which they thought incessantly, had a savor only of regret... Hostile to the past, impatient of the present, and cheated of the future... the only way of escaping from that intolerable leisure was to set the trains running again in one's imagination.

-Albert Camus, The Plague, 1946 
